\title{
Variations in the size of Antarctic krill, Euphausia superba Dana, in small swarms
}

\author{
J. L. Watkins \\ British Antarctic Survey, Natural Environment Research Council, High Cross, Madingley Road, Cambridge CB3 0ET, \\ United Kingdom
}

\begin{abstract}
Studies on the characteristics of krill in individual swarms require sampling methods which ensure that the swarms are sampled discretely. A study on the size composition of krill swarms using an enlarged Longhurst-Hardy plankton recorder (LLHPR) and an echosounder reveal that the length frequency distributions of krill in adjacent swarms were often significantly different. In contrast, length frequency distributions from within the same swarm were not usually significantly different and any differences were probably caused by several swarms overlapping in the LLHPR samples. The size of krill in the samples showed as much variation over short distances (several hundred metres) as over longer distances (several kilometres). Differences in size between adjacent swarms are probably due to a length-dependent sorting mechanism that restricts the size range of krill in the swarm. The presence of a few adults in many juvenile swarms indicate that this mechanism does not always operate.
\end{abstract}

\section{INTRODUCTION}

The formation of swarms is a conspicuous behavioural feature of Antarctic krill, Euphausia superba Dana, and its study is central to an understanding of krill biology. Swarm sizes vary considerably from a superswarm found off Elephant Island (Mathieson \& Macaulay 1983) with an area of square kilometres, to small swarms only metres in diameter. All stages in the life cycle of E. superba swarm (Marr 1962) and the size range of individuals in many of these swarms is quite restricted (Marr 1962, Shevtsov \& Makarov 1969. Mauchline 1980, Kils 1981). Restricted size distributions of individuals in swarms or schools of mysids (Clutter 1969, Zelickman 1974) and fish (Shaw 1978) are also very common.

In some studies it is possible to ascertain visually that samples of krill from separate swarms are distinct, for instance the surface swarms of krill sampled during the day by Marr (1962). However, the krill swarms that are found in mid-water have usually been sampled with large nets such as the RMT8 (Nast 1979, Morris \& Ricketts 1984) or commercial fish trawls (Jazdzewski et al. 1978, Witek et al. 1981). While these samples may be representative of the krill population of the area they provide little information on the composition and structure of individual krill swarms. This study describes the size composition of some individual swarms utilizing 2 complementary high resolution samplers, which together can discriminate between individual swarms. A large Longhurst-Hardy plankton recorder provided serial samples of krill from swarms along a horizontal transect. An echosounder provided a simultaneous 2-dimensional picture of the size and distribution of the krill swarms along the transect.

\section{MATERIALS AND METHODS}

Field sampling. A specially designed, enlarged version of a Longhurst-Hardy plankton recorder was built to take quantitative samples of Euphausia superba. The nose cone had a mouth area of $0.5 \mathrm{~m}^{2}$ and a maximum diameter of $1 \mathrm{~m}$. The net was $3 \mathrm{~m}$ long with a total area of $6.12 \mathrm{~m}^{2}$ and a mesh size of $1.55 \mathrm{~mm}$. The recorder box mounted behind the net had a filtering area of $0.14 \mathrm{~m}^{2}$ and contained the 2 rolls of gauze between which the krill were held. An opening/closing mechanism, controlled acoustically from the ship, was positioned between the net and recorder box. The whole system was held in a rectangular steel frame $6.4 \mathrm{~m}$ long. A full description of the design and construction is given by Bone (in press).

A Simrad EK120 echosounder and a QM integrator were used to provide an acoustic estimate of the krill distribution before and during each haul. In a $6 \mathrm{~d}$ period 24 hauls were made with the LLHPR as part of an intensive study of an area of relatively high krill 
abundance off the northeast coast of South Georgia in January 1982. A grid, $27 \mathrm{n}$ miles square with central co-ordinates $53^{\circ} 46^{\prime} \mathrm{S}, 36^{\circ} 12^{\prime} \mathrm{W}$ (Fig. 1), was acoustic-

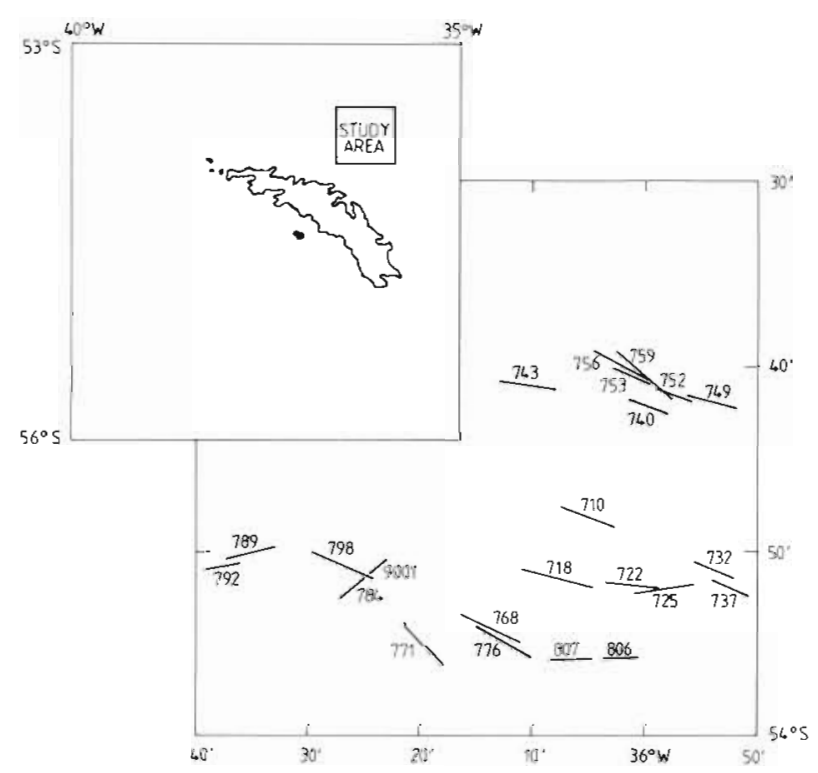

Fig. 1. Location of study area off the northeast coast of South Georgia and location of LLHPR haul tracks

ally surveyed for $3 \mathrm{~d}$ before any LLHPR hauls were made. The LLHPR was towed horizontally at approximately 3 knots. Gauze wind-on intervals of $30 \mathrm{~s}(4$ hauls) or $60 \mathrm{~s}$ were used and from 22 to 74 serial samples were obtained in each haul. Mean towing distances per sample were $57 \mathrm{~m}$ (standard deviation, $\mathrm{S}=7.2)$ and $111 \mathrm{~m}(\mathrm{~S}=10.8)$ for the $30 \mathrm{~s}$ and $60 \mathrm{~s}$ wind-on intervals. This was equivalent to $23.6(\mathrm{~S}=$ 4.1) and $50.2(\mathrm{~S}=6.8) \mathrm{m}^{3}$ of water filtered. The fishing depth for each LLHPR haul was chosen after an acoustic preview run to determine the depth of krill swarms along the proposed transect. The net was opened acoustically at the fishing depth and fished for about $60 \mathrm{~min}$ before being closed and hauled to the surface. Net depth was measured with an Institute of Oceanographic Sciences (IOS) net monitor and a Benthos Inc. standard LHPR control cylinder which also recorded gauze advance intervals. Variations in net depth due to fluctuations in towing speed were compensated for by adjusting the length of the towing wire. However, depth fluctuations of up to $10 \mathrm{~m}$ occurred in many hauls. Flows through and past the net were measured with TSK and IOS flowmeters, respectively.

Laboratory sampling. Samples were sorted immediately after each haul. All krill and macrozooplankton in each sample were counted. The total length, rounded down to the nearest $\mathrm{mm}$, was measured from the anterior edge of the eye to the tip of the telson for up to 100 (mean $=96$ ) Euphausia superba randomly chosen from each sample. Krill longer than $35 \mathrm{~mm}$ total length were selectively subsampled and preserved in $4 \%$ formalin and sexual maturity stages were later determined using the key of Makarov \& Denys (1980)

Data analysis. An allowance for the time differences between acoustically scanning a swarm and taking net samples was calculated from the net depth, the ship's speed and the length of the towing wire. For each haul a 2-way contingency table of counts was constructed classified by length (up to 42 levels) and sample (up to 9 levels depending on the haul). Only those samples where more than 50 krill were measured were included in the analysis. The method tests differences between the length frequency distributions of different samples using a log-linear model (Bishop et al. 1975). The model was fitted with an iterative proportional fitting algorithm (GENSTAT: Alvey et al. 1980).

\section{RESULTS}

During the day fairly discrete, compact swarms were found, usually above the thermocline which was at about $70 \mathrm{~m}$. At night swarms rose to the surface and very few krill were caught in the LLHPR. In 11 of the hauls more than 100 krill were found in at least 2 of the LLHPR samples so that a comparison of the length frequency distributions within the haul was possible. The krill were distributed patchily within a haul and often several adjacent LLHPR samples contained large numbers of krill; such groups of samples have been called aggregations (Fig. 2). In several instances krill were present in samples between the selected aggregations but the numbers were usually several orders of magnitude smaller than those present within the aggregations. The maximum densities in the hauls in Fig. 2 were 31 and $65 \mathrm{krill} \mathrm{m}^{-3}$, respectively.

From the LLHPR samples alone it was not possible to determine whether an aggregation represented a single krill swarm or several swarms separated by distances equal to or less than the sample distance. Some degree of differentiation between closely spaced swarms was possible after net trajectories and LLHPR catches had been plotted on the echocharts because net aggregations often matched with 'krill' marks on the echosounder.

Length frequency histograms (Fig. 3) show that the majority of the krill were juveniles between 20 and $40 \mathrm{~mm}$ in length. Preliminary comparisons of the length frequency distributions of samples within hauls were probably biased by the large number of cells that were empty or had an expected frequency of less than 5, especially in the size classes above $37 \mathrm{~mm}$ (Fig. 3; Zar 1974). To increase the sensitivity of the analysis and to reduce the number of empty cells, classes at the ends of the length frequency distributions were pooled 


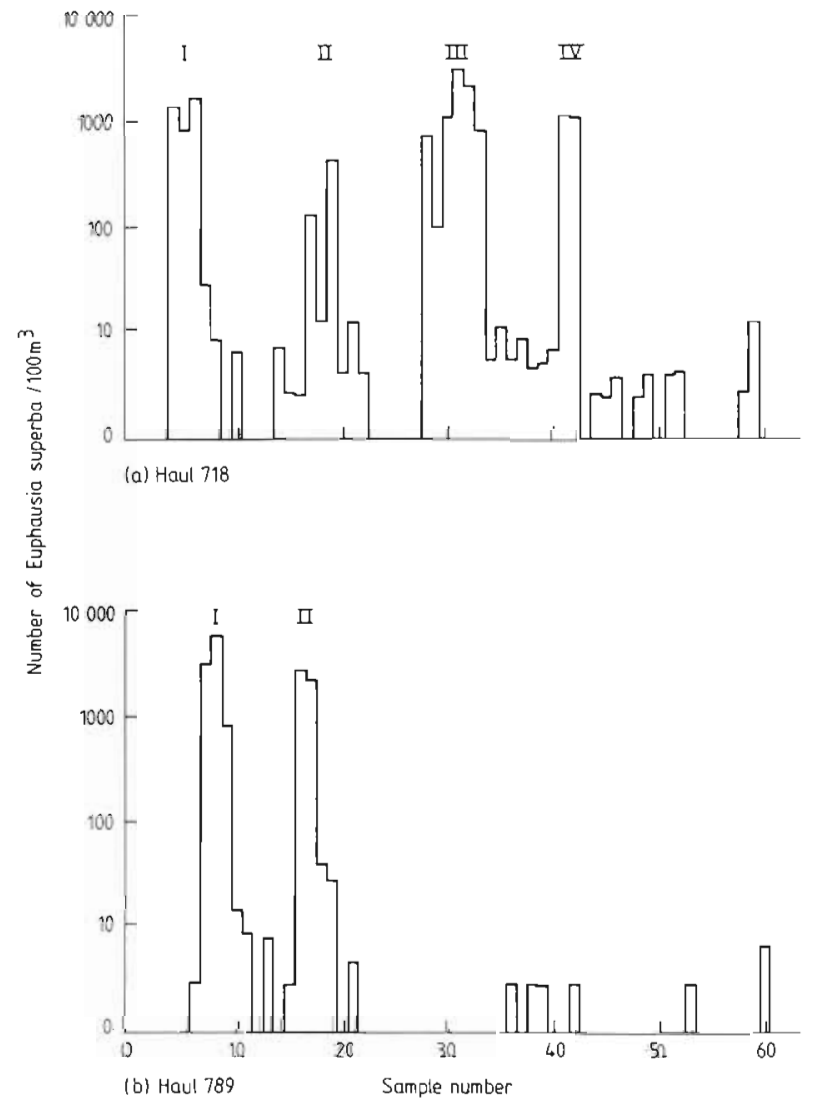

Fig. 2. Euphausia superba. Abundance (number $100 \mathrm{~m}^{-3}$ ) of krill in 2 LLHPR hauls. Roman numerals denote those groups of samples that form aggregations as follows: length classes below $22 \mathrm{~mm}$ were combined to form one new class (17 to $21 \mathrm{~mm}$ ), length classes above $37 \mathrm{~mm}$ were pooled to form 3 new classes (38 to $40 ; 41$ to $50 ; 51$ to $58 \mathrm{~mm}$ ). There were significant differences $(\mathrm{P}<0.01)$ between samples in nearly every haul. The length frequency distributions for those samples within an individual aggregation were then compared by restricting the analysis to each aggregation in turn. Significant differences $(\mathrm{P}<0.05)$ between the samples occurred in 6 of the 13 aggregations tested but only 2 were significant at $P<0.01$ (Table 1). Finally the data were analysed to see whether the overall length frequency distributions of each aggregation (obtained by summing all the length frequencies of the individual samples in the aggregation) within a haul were significantly different. In contrast to the variation between samples within an aggregation the variation between aggregations in a haul was much more pronounced and in all but 2 hauls there were significant differences $(\mathrm{P}<0.01)$ between the aggregations (Table 1). Significant differences between samples within an aggregation may have occurred because of variation within a single krill swarm or because several swarms were not resolved separately by the LLHPR. In Table 2 the aggregations are classified by their appearance on the echocharts and the degree of variation in length frequency distributions. It is likely that at least 4 of the aggregations sampled by the LLHPR were just single swarms which were spread across 2 or 3 samples. The length frequency distribu-
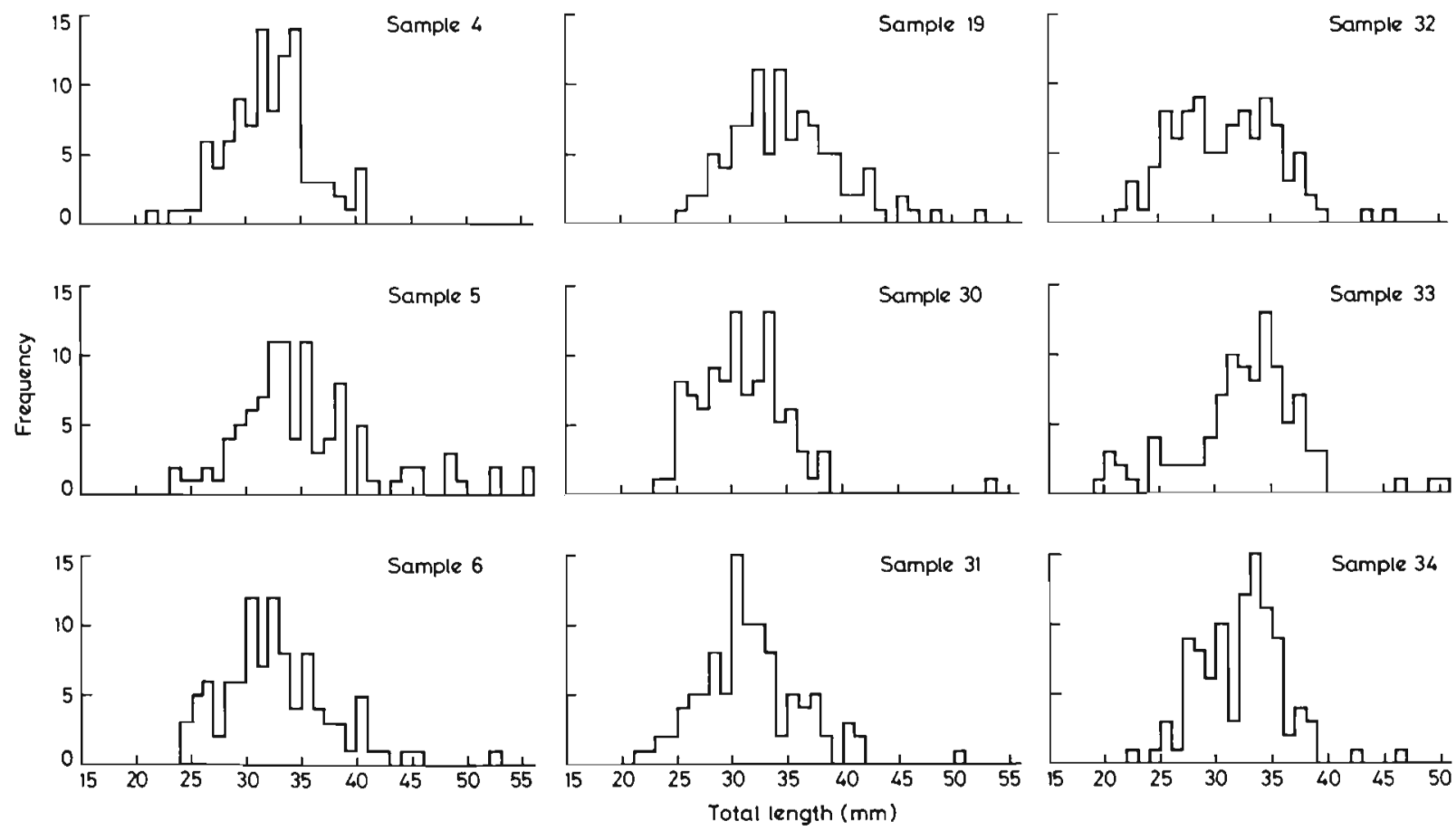

Fig. 3. Euphausia superba. Length frequency histograms for samples in Haul 718 
Table 1. Euphausia superba. Significance values from contingency table analysis of the variation in krill length frequency distributions between samples within the same aggregation and between aggregations in the same haul. NS $=\mathrm{P}>0.05 ; \cdot=$ $0.01<\mathrm{P}<0.05 ; \cdots=\mathrm{p}<0.01$

\begin{tabular}{|c|c|c|c|c|}
\hline \multirow[t]{2}{*}{ Haul } & \multirow[t]{2}{*}{ Aggregation } & \multirow{2}{*}{$\begin{array}{l}\text { Number of samples } \\
\text { analysed in aggregation }\end{array}$} & \multicolumn{2}{|c|}{ Degree of variation } \\
\hline & & & $\begin{array}{l}\text { Between samples } \\
\text { within aggregations }\end{array}$ & $\begin{array}{c}\text { Between aggregations } \\
\text { within hauls }\end{array}$ \\
\hline 710 & $\begin{array}{l}\text { I } \\
\text { II }\end{array}$ & $\begin{array}{l}1 \\
1\end{array}$ & & NS \\
\hline 718 & $\begin{array}{l}\text { I } \\
\text { II } \\
\text { III } \\
\text { IV }\end{array}$ & $\begin{array}{l}3 \\
1 \\
5 \\
1\end{array}$ & $\cdot$ & $\cdots$ \\
\hline 732 & $\begin{array}{l}\text { I } \\
\text { II }\end{array}$ & $\begin{array}{l}2 \\
2\end{array}$ & NS & NS \\
\hline 737 & $\begin{array}{l}\text { I } \\
\text { II }\end{array}$ & $\begin{array}{l}2 \\
1\end{array}$ & NS & $\cdots$ \\
\hline 749 & $\begin{array}{l}\text { I } \\
\text { II }\end{array}$ & $\begin{array}{l}1 \\
1\end{array}$ & & $\cdots$ \\
\hline 752 & $\begin{array}{l}\text { I } \\
\text { II } \\
\text { III }\end{array}$ & $\begin{array}{l}2 \\
1 \\
2\end{array}$ & $\begin{array}{c}\text { NS } \\
.\end{array}$ & $\cdots$ \\
\hline 753 & $\begin{array}{l}\text { I } \\
\text { II }\end{array}$ & $\begin{array}{l}3 \\
1\end{array}$ & . & $\cdots$ \\
\hline 768 & $\begin{array}{l}\text { I } \\
\text { II }\end{array}$ & $\begin{array}{l}2 \\
1\end{array}$ & NS & $\because$ \\
\hline 789 & $\begin{array}{l}\text { I } \\
\text { II }\end{array}$ & $\begin{array}{l}3 \\
2\end{array}$ & $\begin{array}{l}\text { NS } \\
\text { NS }\end{array}$ & $\because$ \\
\hline 792 & I & 2 & $\cdot \cdot$ & \\
\hline 807 & 1 & 2 & NS & \\
\hline
\end{tabular}

Table 2. Euphausia superba. A comparsion of the differences in krill length frequency distributions from the samples within the aggregations with an interpretation of the swarm integrity from plots of net trajectories on the echosounder charts. " $=0.01<\mathrm{P}<0.05 ; \cdots=\mathrm{P}<0.01$. Hauls identified by 3 -figure numbers, identification numbers of the samples within each aggregation shown in brackets

\begin{tabular}{|c|c|c|}
\hline \multirow{2}{*}{$\begin{array}{l}\text { Interpretation of the } \\
\text { occurrence of krill in } \\
\text { LLHPR samples using } \\
\text { EK120 echosounder } \\
\text { chart records }\end{array}$} & \multicolumn{2}{|c|}{$\begin{array}{c}\text { Comparison of } \\
\text { frequency distributions } \\
\text { from adjacent LLHPR samples }\end{array}$} \\
\hline & $\begin{array}{l}\text { Significant } \\
\text { differences }\end{array}$ & $\begin{array}{c}\text { Non-significant } \\
\text { differences }\end{array}$ \\
\hline $\begin{array}{l}\text { Single swarm } \\
\text { extending over } \\
\text { adjacent samples }\end{array}$ & & $\begin{array}{l}732(12,13) \\
752(3,4) \\
768(7,8) \\
789(7,8,9)\end{array}$ \\
\hline $\begin{array}{l}\text { Separate swarms } \\
\text { extending over } \\
\text { adjacent samples }\end{array}$ & $\begin{array}{l}718(4,5,6)^{\circ} \\
752(21,22)^{\circ} \\
753(2,3,4)^{\circ} \\
792(19,20)^{\cdots}\end{array}$ & $\begin{array}{l}789(16,17) \\
807(2,3)\end{array}$ \\
\hline $\begin{array}{l}\text { No obvious swarms } \\
\text { on echo chart }\end{array}$ & $\begin{array}{l}718(30 \ldots 34)^{\circ} \\
732(6,7)^{\bullet}\end{array}$ & $737(9,10)$ \\
\hline
\end{tabular}

tions of samples within these aggregations were not significantly different $(P>0.05)$. Echograms for the other aggregations showed that the samples may have been taken from more than one swarm as there were several swarms within $\pm 2 \mathrm{~min}$ and $\pm 5 \mathrm{~m}$ of the sample time and depth. Some of these aggregations had highly significant differences $(P<0.01)$ in the length frequency distributions. A third category was included because 3 aggregations were sampled when there were no obvious krill marks on the echochart. Length frequency distributions for 2 aggregations within which significant differences occurred can be compared with a non-significant distribution in Fig. 4. In Aggregation I in Haul 753, 2 swarms containing different sized krill were probably sampled. Mixing of the swarms produced the bimodal size distributions in the first 2 samples in which the relative size of the 2 peaks changed. The size distribution in the third sample was unimodal and the krill were probably from just a single swarm. In Aggregation I in Haul 792, 2 swarms were also sampled; while the median size of the krill was the same in both samples, the range of krill sizes in the first was greater than in the second. In this case it is not clear which krill came from the first swarm and 
(a)
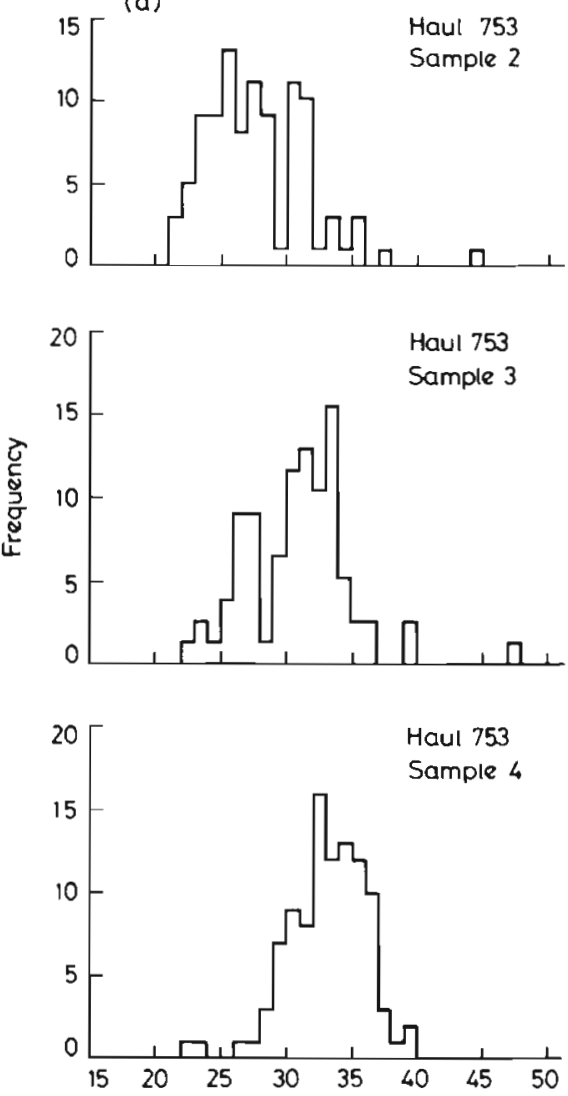

(b)

(c)
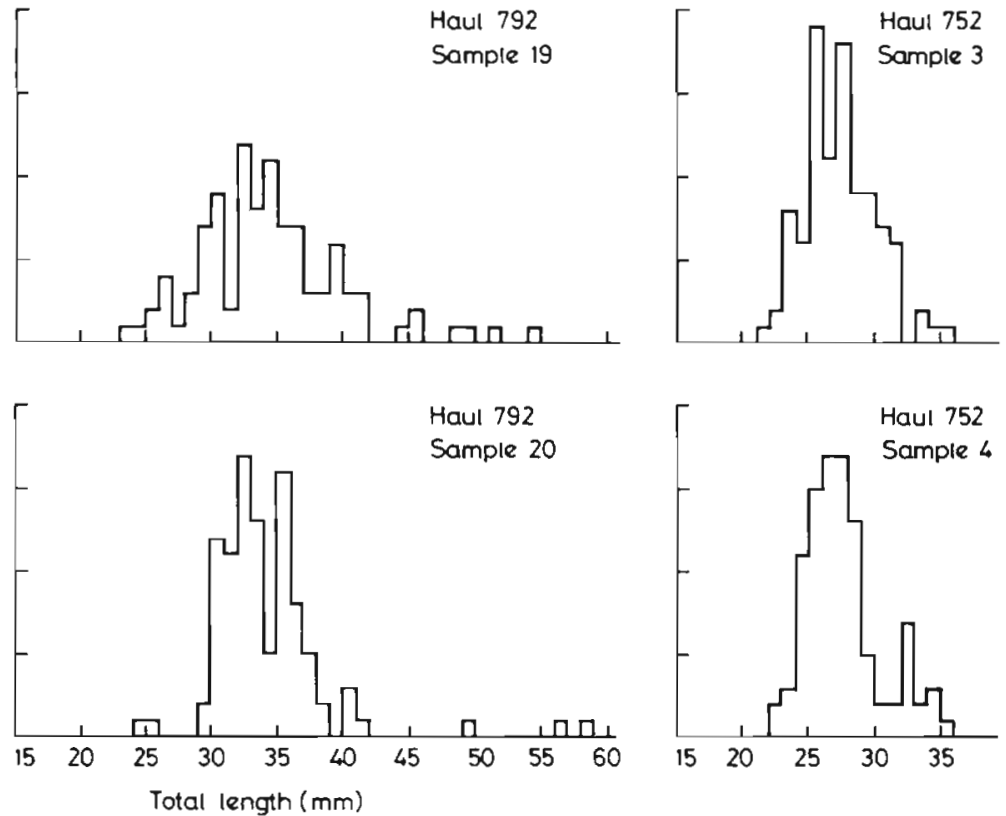

Fig. 4. Euphausia superba. Length frequency histograms for samples from aggregations within which significant differences $(P<0.01)$ in length frequency occurred: (a) Haul 753, Aggregation I, and (b) Haul 792, Aggregation I; and for an aggregation within which there were no significant differences: (c) Haul 752, Aggregation I

which came from the second. In contrast, in Haul 752 the adjacent samples have similar length frequency distributions and appear to be from a single swarm. Therefore, differences in the size composition of samples within an aggregation were a result of sampling several swarms together rather than size differences between samples from a single swarm.

The depth of the LLHPR fluctuated due to variations in the towing speed and it is possible that small depth changes during a haul contributed to the differences observed between samples. Changes in depth of up to $10 \mathrm{~m}$ were observed but depth changes between consecutive samples were rarely more than 2 or $3 \mathrm{~m}$. There was no correlation between the median size of krill and the depth of individual samples in the hauls $(r=$ $-0.23, \mathrm{n}=42,0.1<\mathrm{P}<0.2$ ). More relevant than the actual median size and depth is whether small changes in the median size are caused by changes in the depth from which the krill samples were taken. However, the magnitude of the change of the median size of krill in samples in a haul was not related to differences in the depth from which those samples were taken $(\mathrm{r}=0.14$, $P>0.2$ ).
There was no correlation between the difference in the median size of the krill and the distance between the samples within a haul (Spearman rank correlation coefficient $r_{\mathrm{s}}=-0.03, \mathrm{P}>0.1$ ). Differences in median sizes between samples were usually only 1 or $2 \mathrm{~mm}$ although a difference of $10 \mathrm{~mm}$ occurred between 2 samples separated by $1.3 \mathrm{~km}$ in Haul 737. However, with samples only $100 \mathrm{~m}$ apart differences of up to $6 \mathrm{~mm}$ occurred, thus the distance between samples gave no indication of the variation in median krill length between swarms.

The length frequency distributions of krill in adjacent samples were often significantly different. These differences could be due either to the fact that the median or mean size of the krill was different or to changes in the variance of the distributions. Although the variance of the sample distributions varied greatly it was usually less than that for the total population. There was a significant positive correlation between mean size and variance $(\mathrm{r}=0.58, \mathrm{t}=4.50, \mathrm{P}<0.001)$. In many cases this was due to the presence of a few large krill between 40 and $55 \mathrm{~mm}$ in addition to the krill in the size range 20 to $40 \mathrm{~mm}$. This was particu- 
larly apparent in the first 3 samples in Haul 718 in Fig. 2 which had variances of $14.4,43.2$ and 25.3, respectively.

Only $3.9 \%$ of all the krill sampled were adults, which were usually present in low numbers in many samples. However, in Haul 737 the median length of krill was $47 \mathrm{~mm}$ and over $60 \%$ of the krill were adults. The adult male to female ratio was $1: 1.6$, however, the male to female ratio when subadults were included was $3.8: 1$. This difference was due to the high proportion of subadult males within the size range 32 to $40 \mathrm{~mm}$, which were easily detectable in the preserved subsamples by the presence of the developing petasma. The lower frequency of occurrence of subadult females in this size range may be because the thelycum developed later or was less easily detected causing undifferentiated females to be classified as juveniles. It may, however, have reflected a true difference in the sex ratio of the subsamples. Whichever is correct, it is valid to look for differences between the sex ratios of the subsamples (Table 3). Chi-squared

Table 3. Euphausia superba. Percentage of subadult and adult males found in selectively subsampled LLHPR samples

\begin{tabular}{|cccc|}
\hline Haul & $\begin{array}{c}\text { Sample } \\
\text { identification } \\
\text { number }\end{array}$ & $\begin{array}{c}\text { Percentage } \\
\text { male }\end{array}$ & $\begin{array}{c}\text { Number in } \\
\text { sample }\end{array}$ \\
\hline 732 & 6 & 64 & 47 \\
& 7 & 74 & 19 \\
737 & 12 & 78 & 51 \\
& 13 & 71 & 17 \\
& 9 & 63 & 24 \\
768 & 10 & 39 & 44 \\
& 28 & 43 & 14 \\
792 & 33 & 74 & 31 \\
& 8 & 94 & 32 \\
& 17 & 100 & 32 \\
807 & 19 & 92 & 13 \\
& 20 & 70 & 37 \\
& 2 & 82 & 28 \\
& 3 & 67 & 36 \\
& & 63 & 16 \\
\hline
\end{tabular}

tests indicated that there were significant differences ( $\mathrm{P}<0.001$ ) when all the subsamples were compared. However, there was much less variation between samples within individual hauls; the only significant result was in Haul $737(\mathrm{P}<0.02)$. In Haul 792 there was no significant difference $(\mathrm{P}>0.2)$ in the sex ratio of the subsamples although there was a significant difference in the size composition of the subsamples.

\section{DISCUSSION}

The densities calculated from the LLHPR were low when compared with visual estimates of 50,000 to
60,000 $\mathrm{krill} \mathrm{m}^{-3}$ (Hamner et al. 1983). However, the decrease in krill numbers as a result of net avoidance does not influence the conclusions of this study provided that the krill caught in each sample were representative of the krill in that part of the swarm. Unfortunately, as with most net studies, it was not possible to know if the size composition of the samples caught with the LLHPR were truly representative of the respective swarms or aggregations. However, the size distributions of the LLHPR samples were compared with RMT8 (8 $\mathrm{m}^{2}$ net) samples to see if larger krill were better able to avoid the smaller mouth opening of the LLHPR. Surprisingly the mean size of krill caught in the LLHPR was significantly larger than that from an extensive series of RMT8 samples taken from the same area a week earlier (Kolmogorov-Smirnov test, $\mathrm{P}<0.001)$.

Virtually no krill were caught in the LLHPR hauls made during the dark, and echotraces showed that the krill rose to the surface at night. Such night-time surface migrations are quite common (Marr 1962, Witek et al. 1981). In one night-time haul at a depth of approximately $25 \mathrm{~m}$ a few krill were found in nearly every sample, although no krill were detected by the echosounder, so it is probable that the krill swarms dispersed at night. Kalinowski (1978) and Everson (1982) also found that swarms dispersed at night and individual swarms were not distinguishable on the echocharts. There are no data on the structure of these dispersed swarms but mixing of swarms is likely to occur at this time. Clutter (1969) found that the mysid Metamysidopsis elongata also dispersed in the dark. Wittman (1977) noted that marked mysids had often moved to another swarm when observed the following day. In contrast, Hamner et al. (1983) observed discrete swarms of Euphausia superba at night. If swarms do mix then the composition of the new swarms will depend initially on the degree of mixing that occurred during the dispersed phase.

The size composition of swarms separated by several hundred metres may be as different as swarms separated by several kilometres. Therefore, swarms forming after a period of dispersion and mixing are likely to be composed of individuals of various sizes from adjacent swarms. The significant differences in the length frequency distributions of the swarms indicate that the krill in a swarm are not a random mixture from the area sampled. Therefore, some degree of sorting on the basis of length probably occurs, producing the restricted length frequency distributions found in some swarms (for instance Sample 4, Haul 753; Sample 20, Haul 792; Fig. 4). Two length-dependent sorting mechanisms have been proposed. Mauchline (1980) suggested that swarms sort due to size-dependent swimming speeds, and this mechanism has been 
abserved by divers (Hamner et al. 1983). Kils (1981) proposed that krill sort due to their differential sinking rates. The latter mechanism could be especially important if the krill were dispersed at the surface during the night. Unfortunately from the present study there was no indication of changes in mean size with depth nor of changes in swarm variance with the time of swarm dispersion or reaggregation. Analysis of length frequency distributions of RMT8 samples during a $6 \mathrm{~d}$ period, just prior to the present study, indicate that the mean length of krill was different for each depth range in each time period on every day (Watkins et al. 1985). Even if sorting by length is possible it is certainly not a universal occurrence. Hamner et al. (1983) observed a single swarm with a bimodal size distribution that divided only when forced to swim faster. In this study swarms containing large numbers of adult krill were found in only one haul, more frequently a few adults would be found as part of a juvenile swarm. Therefore, it appears that larger krill modified their size-dependent swimming speeds and so remained with the majority of small krill rather than exist as isolated individuals or groups. Clutter (1969) observed that small groups of mysids only maintained their integrity if they remained more than a critical distance apart.

The results from this study of changes in the size composition of swarms have shown that each swarm is a non-random grouping of krill, that the swarm may have a restricted size distribution and that adjacent swarms may be as different as swarms kilometres apart. Some krill swarms also probably segregate by moult stage (Buchholz 1985) and, in areas that contain swarms of adult krill, by sex and maturity stage (Marr 1962). Thus the factors affecting swarm composition and sorting mechanisms must be even more complex than outlined here.

Acknowledgements. I thank the Master and crew of the RRS John Biscoe, and all members of the British Antarctic Survey Offshore Biological Programme for help in collecting and analysing the samples. I thank D. G. Bone for designing, building and running the LLHPR, Dr. C. Ricketts for help with the design and analysis of the experiments, Dr. I. Everson for the helpful discussions and comments on the manuscript

\section{LITERATURE CITED}

Alvey, N. G., Banfield, C. F., Baxter, R. I., Gower, J. C., Krzanowski, W. J., Lane, P. W., Nelder, J. A., Payne, R. W., Phelps, K. M., Rogers, C. E., Ross, G. J. S., Simpson, H. R., Todd, A. D., Wedderburn, R. W. M., Wilkinson, G. N. (1980). GENSTAT: a general statistical program. Numerical Algorithms Group. Oxford

Bishop, Y. M. M., Fienberg, S. E., Holland, P. W. (1975). Discrete multivariate analysis. MIT Press, Cambridge
Bone, D. G. (in press). An LHPR system for adult krill (Euphausia superba). Br. Ant. Sur. Bull

Buchholz, F. (1985). Moult and growth in euphausiids. In: Siegfried, W R., Condy, P. R., Laws, R. M. (ed.) Antarctic nutrient cycles and food webs. Springer-Verlag, Berlin, p. 339-345

Clutter, R. I. (1969). The microdistribution and social behaviour of some pelagic mysid shrimps. J. exp. mar. Biol. Ecol. 3: 125-155

Everson, I. (1982). Diurnal variation in mean volume backscattering strength of an Antarctic krill (Euphausia superbal patch. J. Plankton Res. 4: 155-162

Hamner, W. M., Hamner, P. P., Strand, S. W., Gilmer, R. W. (1983). Behavior of Antarctic krill, Euphausia superba: chemoreception, feeding, schooling, and molting. Science, N.Y 220: 433-435

Jazdzewski, K., Szik, J., Porebski, J., Rakusa-Suszczewski, S., Witek, Z., Wolnomiejski, N. (1978). Biological and populational studies on krill near South Shetland Islands, Scotia Sea and South Georgia in the summer 1976. Polskie Arch. Hydrobiol. 25: 607-631

Kalinowski, J. (1978). Vertical migration of krill in the region of South Georgia, February-March 1976. Polskie Arch. Hydrobiol. 25: 573-583

Kils, U. (1981). Size dissociation in krill swarms. Kieler Meeresforsch. (Sonderh.) 5: 262--263

Makarov, R. R., Denys, C. J. (1980). Stages of sexual maturity of Euphausia superba. BIOMASS Handbook, No 11 . SCAR, Cambridge

Marr, J. W. S. (1962). The natural history and geography of the Antarctic krill (Euphausia superba Dana). 'Discovery' Rep. 32: $33-464$

Mathieson, O. A., Macaulay, M. C. (1983). The morphological features of a superswarm of krill, Euphausia superba. In: Nemoto, T., Matsuda, T (ed.) Proceedings of the BIOMASS colloquium in 1982. National Institute Polar Research, Tokyo, p. 153-164

Mauchline, J. (1980). The biology of mysids and euphausiids. Adv. mar. Biol. 18: 1-681

Morris, D. J., Ricketts, C. (1984). Feeding of krill around South Georgia I. A model of feeding activity in relation to depth and time of day. Mar. Ecol. Prog. Ser. 16: 1-17

Nast, F. (1979). The vertical distribution of larval and adult krill (Euphausia superba Dana) on a time station south of Elephant Island, South Shetlands. Meeresforschung 27: 103-118

Shaw, E. (1978). Schooling fishes. Am. Scient. 66: 166-176

Shevtsov, V. V., Makarov, P. P. (1969). On the biology of krill. Trudy VNIRO 66: 177-206

Watkins, J. L., Morris, D. J., Ricketts, C. (1985). Nocturnal changes in the mean length of a euphausid population: vertical migration, net avoidance, or experimental error? Mar. Biol. 86: 123-127

Witek, Z., Kalinowski, J., Grelowski, A., Wolnomiejski, N. (1981). Studies of aggregations of krill (Euphausia superba). Meeresforschung 28: 228-243

Wittman, K. J. (1977). Modification of association and swarming in north adriatic Mysidacea in relation to habitat and interacting species. In: Keegan, B. F., O'Ceidigh, P., Boaden, P. J. S. (ed.) Biology of benthic organisms. Pergamon Press, London, p. 605-612

Zar, J. H. (1974). Biostatistical analysis. Prentice Hall, New Jersey

Zelickman, E. A. (1974). Group orientation in Neomysis mirabilis (Mysidacea: Crustacea). Mar. Biol. 24: 251-258 